\title{
Growth performance and nutrient digestibility of broiler chickens fed diets
} substituted for maize with two varieties of cassava tuber

${ }^{1}$ Obadimu, A. O., ${ }^{1}$ Oluwatosin, O. O., ${ }^{2}$ Sanni, L. O. and ${ }^{1}$ Lala, A. O.

${ }^{\prime}$ Department of Animal Nutrition,

${ }^{2}$ Department of Food Science and Technology,

Federal University of Agriculture, Abeokuta, Ogun State, Nigeria

Corresponding author: fafunwafikayo@yahoo.com (+23407032566939)

\begin{abstract}
A 56-day study was conducted to determine the growth performance and nutrient utilization of broiler chickens fed with two varieties (white and yellow) of cassava grit based diets. A total of 240 one day-old unsexed Arbor acre broiler chicks were assigned to eighty dietary treatments in a $2 \times 4$ factorial arrangement using completely randomized design. Diets were formulated to include two varieties of cassava, TME 419 (white) and TMS 011368 (yellow) at four inclusion levels (0, 25, 50 and 75\%). Each treatment consisted of 30 birds and three replicates of 10 birds each. Data was collected on growth performance and nutrient digestibility at the end of the starter ( $4^{\text {th }}$ week) and finisher $\left(8^{\text {th }}\right.$ week) phases. At the starter phase, birds fed 50\% white cassava grits diet had the highest $(P<0.05)$ final weight and weight gain $(730.00$ and $693.67 \mathrm{~g} / \mathrm{bird})$. At the finisher phase, birds fed $50 \%$ yellow cassava grits diet had the highest $(P<0.05)$ final weight and weight gain $(2235.60$ and $1454.00 \mathrm{~g} / \mathrm{bird})$, respectively while the least final weight and weight gain values (2008.80 and $1267.80 \mathrm{~g} /$ birds) were obtained in birds fed the control diet. At the starter phase, birds fed $75 \%$ white cassava grits diet had the best $(P<0.05)$ feed conversion ratio of 2.18 , while birds fed 25\% yellow cassava grits diet as well as those fed the control diet had the least $(P<0.05)$ feed conversion ratio of 2.62 and 2.51, respectively. Birds fed $50 \%$ yellow as well as those fed $75 \%$ yellow cassava grits diets had the highest dry matter and crude fibre digestibility at the starter and finisher phases, respectively. In conclusion the substitution of maize with white cassava grits up to 50\% level improved growth performance at the starter phase. However, either white or yellow cassava can be substituted for maize up to $75 \%$ at the finishing phase.
\end{abstract}

Keywords: Growth, digestibility, white cassava, yellow cassava, broiler chickens

\section{Introduction}

The daily minimum protein requirement of an adult varies between $65-85$ g per person, out of which $35 \mathrm{~g}$ of this minimum requirement should be obtained from animal products (Oloyede, 2005). The average per capital protein intake in Nigeria was reported to be $51.7 \mathrm{~g}$ per person/day from which only $8.6 \mathrm{~g}$ came from animal sources (Charts, 2011). This observed low animal protein consumption may be attributed to the declining animal protein production occasioned by high cost of livestock production especially the cost of feeds which usually accounts for up to $70 \%$ of the total cost of production (Iyayi et al.,
2002).

Maize is the commonly used source of energy in livestock feeds (Olurin et al., 2006). The rapid growth of human population has intensified the competition between man and livestock for cereals such as maize, resulting to high cost of the cereal grains and consequently high prices of poultry products. Therefore, it is necessary to look for alternative and cheaper sources of energy that can replace maize to reduce cost of production and contribute to increased supply of animal protein at an affordable price; one of such economical substitute ingredient for maize is cassava meal (Anthony, 2009). Cassava is regarded 


\section{Growth performance and nutrient digestibility of broiler chickens}

as one of the world's top calorie producer for human and livestock consumption. It can be grown on poor soil without additional extraneous fertilizer and can survive prolonged dry spell (Alves and Settler, 2000). It is estimated that most $(65 \%)$ of cassava crop is used for human consumption, while the remaining is used for animal feed, starch and industrial application (Balogun and Bawa, 1997). The pelletized nature of the cassava grits makes it more desirable for use in poultry feeding than the flour. This is because grits reduce dustiness which causes irritation of the respiratory tract (Apata and Babalola, 2012).

This study was carried out to evaluate the effects of substituting maize with white and yellow varieties of cassava grits at varying levels in the diets of broiler chickens.

\section{Materials and methods \\ Preparation of experimental material (Cassava grits)}

A total of $1000 \mathrm{~kg}$ cassava tubers of $500 \mathrm{~kg}$ each of the two cassava varieties (TME 419 (white) and TMS 011368 (yellow)) was obtained and processed into two separate cassava grits. The tubers were peeled, washed, grated and pressed with a hydraulic press to remove water content where 60-70 $\%$ moisture content was retained in the cassava in order to form grits during frying. The dewatered cassava paste was pulverized and fried using motorized frying machine. The cassava grits were cooled, sieved to separate the particle sizes for the different stages of broiler production. The analysed white cassava grits contained 2.40 $\%$ crude protein $(\mathrm{CP}), 3.50 \%$ crude fibre (CF), $2.50 \%$ ether extract (EE), $1.00 \%$ ash and $3154.60 \mathrm{kcal} / \mathrm{kg}$ metabolizable energy (ME). While the yellow cassava grits contained $2.57 \% \mathrm{CP}, 3.60 \% \mathrm{CF}, 2.00 \%$ EE, $2.00 \%$ ash and $3199.19 \mathrm{kcal} / \mathrm{kg} \mathrm{ME}$.

\section{Experimental diets and design}

A total of 240 one day-old unsexed broiler chicks were allotted into eight treatments of 30 birds and each treatment was replicated three times with 10 birds each. The experimental design used was completely randomized design in a $2 \times 4$ factorial arrangement of two cassava varieties (TME-419 (white) and TMS 011368 (yellow) and four substitution levels $(0,25$, 50 and $75 \%$ ) of maize with cassava grits in the diets. Experimental diets were formulated for the starter (0-28 days) and finisher (28-56 days) phases as shown in Tables 1 and 2, respectively.

\section{Data Collection \\ Growth performance}

The initial body weight of the birds was recorded at the beginning of the experiment and subsequently on weekly basis till the end of experiment to determine their weekly body weights and weight gain. Daily feed intake was recorded by deducting the left over feed from initial feed supplied and feed conversion ratio was calculated. Mortality was recorded as it occurred and calculated as percentage of birds in each replicate.

\section{Apparent nutrient digestibility}

At the end of starter and finisher phases of the experiment, two birds per replicate were randomly selected and transferred to clean disinfected metabolic cages. A three- day acclimatization period was allowed prior to the collection of excreta. Thereafter, records of feed supplied, feed intake and voided excreta sample were collected on daily basis for three consecutive days, weighed and dried at $60^{\circ} \mathrm{C}$. The dried excreta samples were pooled together and proximate composition of the experimental diets and excreta samples were used to determine various proximate constituents (dry matter, crude protein, crude fibre, ether extract and ash percentage) by the methods of AOAC (2000). Values obtained were used to determine the digestibility of constituent nutrients. 
Obadimu, Oluwatosin, Sanni and Lala

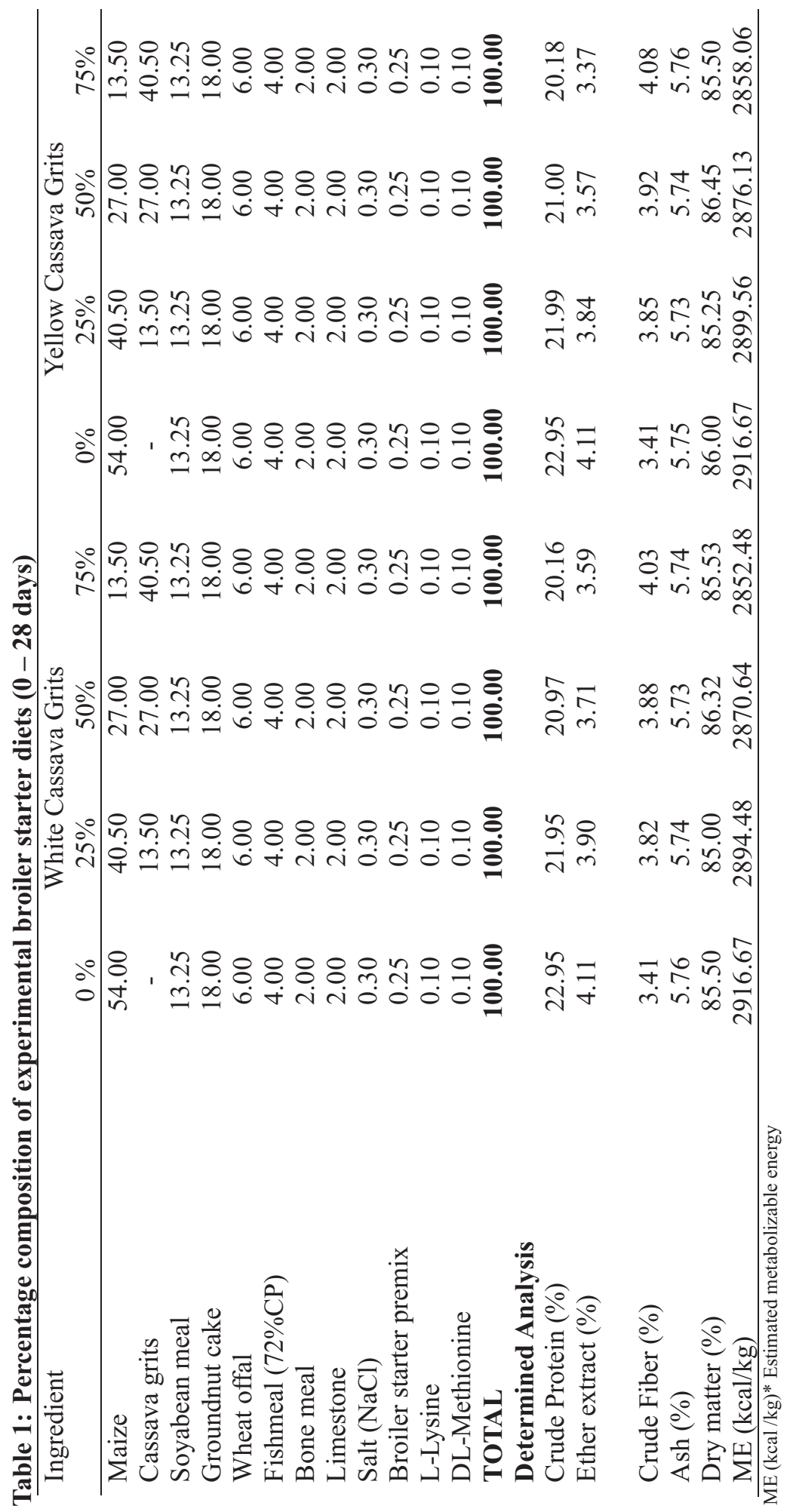




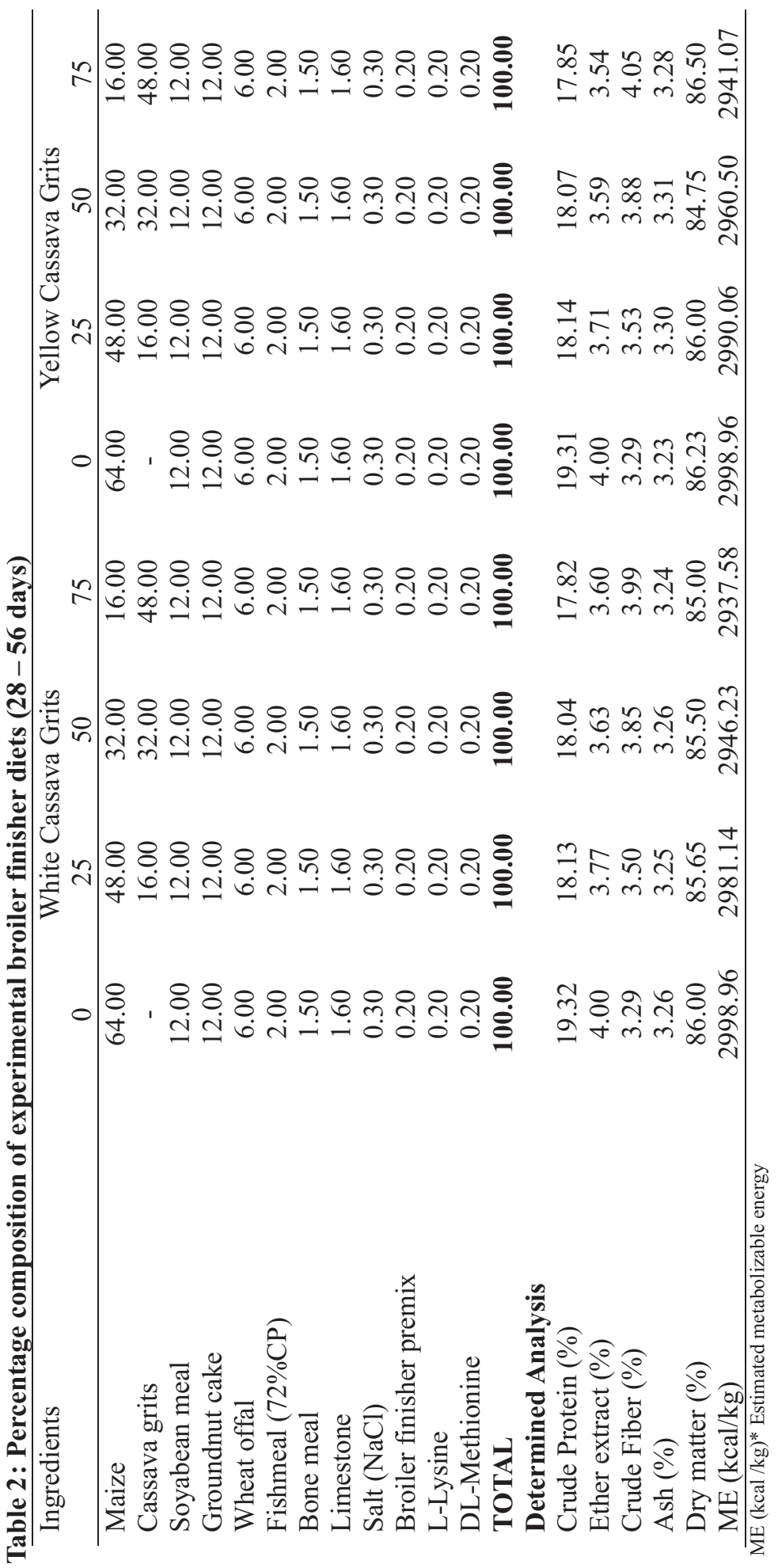




\section{Obadimu, Oluwatosin, Sanni and Lala}

\section{Statistical analysis}

The data generated were subjected to Analysis of Variance (ANOVA) in a $2 \times 4$ factorial arrangement. Significant $(\mathrm{P}<0.05)$ differences among treatment means were separated using Duncan's Multiple Range Test as contained in Statistical Analysis Systems (SAS, 2011). The experimental model is;

$$
\gamma_{\mathrm{ijk}}=\mu+\mathrm{G}_{\mathrm{i}}+\mathrm{V}_{\mathrm{j}}+(\mathrm{GV})_{\mathrm{ij}}+\Sigma_{\mathrm{ijk}}
$$

Where:

$\gamma_{\mathrm{ijk}}=$ Observed value of dependent variable

$\mu=$ Population mean (overall mean)

$\mathrm{G}_{\mathrm{i}}=$ Effect of cassava grits inclusion levels (i=0, 25, 50, 75)

$\mathrm{V}_{\mathrm{j}}=$ Effects of cassava variety $(\mathrm{j}=$ white and yellow)

$(\mathrm{GV})_{\mathrm{ij}}=$ Interactive effect of cassava grits inclusion levels and cassava variety

$\Sigma_{\mathrm{ijk}}=$ Random residual error

\section{Results}

Table 3 showed that cassava grits levels and cassava variety were significant $(\mathrm{P}<0.05)$ for the average final weight, average weight gain, average feed intake, feed conversion ratio and mortality for starting broiler chickens. The highest average final weight $(798.67 \mathrm{~g} / \mathrm{bird})$ and average weight gain $(762.00 \mathrm{~g} / \mathrm{bird})$ were obtained from birds fed diet substituted with $50 \%$ white cassava grits.

The highest $(\mathrm{P}<0.05)$ average feed intake was recorded from birds offered diet containing $25 \%$ yellow cassava grits, while the least feed intake was obtained from birds fed $75 \%$ white cassava grits substitution. The best feed conversion ratio of 2.18 was obtained with birds fed diet substituted with $75 \%$ white as well as those fed $0 \%$ white cassava grits diet (2.24). Growth performance of finishing broiler chickens as shown in Table 4 indicated that inclusion levels of cassava grits and cassava variety was not significant for average final weight, average weight gain and feed conversion ratio. However, average feed intake was significantly $(\mathrm{P}<0.05)$ affected. The average feed intake had the highest value for birds fed diet of $50 \%$ level of yellow cassava grits inclusion and lowest value was obtained for birds fed diet containing $0 \%$ level of yellow cassava grits.

\begin{tabular}{|c|c|c|c|c|c|c|c|}
\hline $\begin{array}{c}\text { Substitution } \\
\text { level }(\%)\end{array}$ & Variety & $\begin{array}{l}\text { Average } \\
\text { initial } \\
\text { weight } \\
\text { (g/bird) }\end{array}$ & $\begin{array}{c}\text { Average } \\
\text { final } \\
\text { weight } \\
\text { (g/bird) }\end{array}$ & $\begin{array}{l}\text { Average } \\
\text { weight } \\
\text { gain } \\
\text { (g/bird) }\end{array}$ & $\begin{array}{c}\text { Average } \\
\text { feed intake } \\
\text { (g/bird) }\end{array}$ & $\begin{array}{c}\text { Feed } \\
\text { conversion } \\
\text { ratio }\end{array}$ & Mortality \\
\hline 0 & White & 33.67 & $795.74^{b}$ & $759.41^{b}$ & $1700.32^{\mathrm{c}}$ & $2.24^{\mathrm{ef}}$ & $0.00^{\mathrm{b}}$ \\
\hline 25 & White & 36.33 & $748.67^{\mathrm{d}}$ & $711.00^{\mathrm{d}}$ & $1767.32^{b}$ & $2.48^{\mathrm{b}}$ & $0.33^{b}$ \\
\hline 50 & White & 37.00 & $798.67^{\mathrm{a}}$ & $762.00^{\mathrm{a}}$ & $1719.32^{b}$ & $2.28^{\mathrm{de}}$ & $0.00^{\mathrm{b}}$ \\
\hline 75 & White & 37.67 & $775.00^{c}$ & $738.33^{c}$ & $1612.32^{\mathrm{d}}$ & $2.18^{f}$ & $0.00^{\mathrm{b}}$ \\
\hline 0 & Yellow & 37.00 & $730.00^{c}$ & $693.67^{\mathrm{e}}$ & $1649.68^{\mathrm{cd}}$ & $2.38^{\mathrm{c}}$ & $0.00^{\mathrm{b}}$ \\
\hline 25 & Yellow & 36.33 & $750.00^{d}$ & $713.00^{\mathrm{d}}$ & $1865.68^{\mathrm{a}}$ & $2.62^{\mathrm{a}}$ & $0.00^{\mathrm{b}}$ \\
\hline 50 & Yellow & 37.33 & $781.67^{\mathrm{bc}}$ & $744.33^{b c}$ & $1758.00^{\mathrm{b}}$ & $2.36^{\mathrm{c}}$ & $0.00^{\mathrm{b}}$ \\
\hline 75 & Yellow & 36.33 & $748.15^{d}$ & $711.81^{\mathrm{d}}$ & $1653.32^{\mathrm{cd}}$ & $2.33^{\mathrm{cd}}$ & $6.67^{\mathrm{a}}$ \\
\hline Pooled SEM & & 0.19 & 5.93 & 5.90 & 17.20 & 0.03 & 0.08 \\
\hline 0 & - & 37.00 & 748.41 & 711.41 & 1710.16 & $2.40^{\mathrm{ab}}$ & $0.05^{\mathrm{a}}$ \\
\hline 25 & - & 36.67 & 773.33 & 736.67 & 1714.52 & $2.33^{\mathrm{ab}}$ & $0.17^{\mathrm{ab}}$ \\
\hline 50 & - & 36.67 & 772.87 & 736.20 & 1783.00 & $2.43^{\mathrm{a}}$ & $0.00^{\mathrm{b}}$ \\
\hline 75 & - & 37.00 & 778.33 & 741.33 & 1685.16 & $2.27^{\mathrm{b}}$ & $0.00^{\mathrm{b}}$ \\
\hline SEM level & & 0.41 & 8.90 & 8.74 & 33.04 & 0.05 & 0.09 \\
\hline- & White & 36.75 & $752.45^{\mathrm{b}}$ & $715.70^{\mathrm{b}}$ & 1732.16 & $2.42^{\mathrm{a}}$ & 0.25 \\
\hline - & Yellow & 36.92 & $784.02^{\mathrm{a}}$ & $747.10^{\mathrm{a}}$ & 1714.24 & $2.29^{b}$ & 0.08 \\
\hline SEM variety & & 0.28 & 7.05 & 6.99 & 24.40 & 0.04 & 0.11 \\
\hline
\end{tabular}




\section{Growth performance and nutrient digestibility of broiler chickens}

Table 4: Effects of cassava grits substitution levels and cassava variety on the growth performance of finishing broiler chickens (28 -56 days)

\begin{tabular}{cccccccc}
\hline $\begin{array}{c}\text { Substitution } \\
\text { level (\%) }\end{array}$ & Variety & $\begin{array}{c}\text { Average } \\
\text { initial } \\
\text { weight } \\
\text { (g/bird) }\end{array}$ & $\begin{array}{c}\text { Average } \\
\text { final } \\
\text { weight } \\
\text { (g/bird) }\end{array}$ & $\begin{array}{c}\text { Average } \\
\text { weight } \\
\text { gain } \\
(\mathrm{g} / \mathrm{bird})\end{array}$ & $\begin{array}{c}\text { Average } \\
\text { feed intake } \\
(\mathrm{g} / \mathrm{b} \text { bird })\end{array}$ & $\begin{array}{c}\text { Feed } \\
\text { conversion } \\
\text { ratio }\end{array}$ & $\begin{array}{c}\text { Mortality } \\
(\%)\end{array}$ \\
\hline 0 & White & $795.74^{\mathrm{b}}$ & 2183.10 & 1366.50 & $3043.32^{\mathrm{c}}$ & 2.24 & $1.67^{\mathrm{a}}$ \\
25 & White & $748.67^{\mathrm{d}}$ & 2125.90 & 1377.30 & $3130.00^{\mathrm{bc}}$ & 2.27 & $1.33^{\mathrm{ab}}$ \\
50 & White & $798.67^{\mathrm{a}}$ & 2213.90 & 1418.10 & $3146.68^{\mathrm{b}}$ & 2.24 & $1.33^{\mathrm{ab}}$ \\
75 & White & $775.00^{\mathrm{c}}$ & 2208.30 & 1433.30 & $3173.32^{\mathrm{ab}}$ & 2.23 & $1.00^{\mathrm{ab}}$ \\
0 & Yellow & $730.00^{\mathrm{c}}$ & 2008.80 & 1278.80 & $2940.00^{\mathrm{d}}$ & 2.51 & $1.00^{\mathrm{ab}}$ \\
25 & Yellow & $750.00^{\mathrm{d}}$ & 2147.90 & 1397.90 & $3140.00^{\mathrm{c}}$ & 2.29 & $0.33^{\mathrm{b}}$ \\
50 & Yellow & $781.67^{\mathrm{bc}}$ & 2235.60 & 1454.00 & $3256.68^{\mathrm{a}}$ & 2.24 & $1.00^{\mathrm{ab}}$ \\
75 & Yellow & $748.15^{\mathrm{d}}$ & 2015.30 & 1267.10 & $3203.32^{\mathrm{ab}}$ & 2.33 & $1.00^{\mathrm{ab}}$ \\
Pooled SEM & & 5.93 & 27.84 & 26.15 & 5.26 & 0.04 & 0.12 \\
0 & - & 748.41 & 2070.60 & 1322.20 & 3035.00 & 2.30 & 1.33 \\
25 & - & 773.33 & 2095.97 & 1322.64 & 3123.32 & 2.37 & 0.83 \\
50 & - & 772.81 & 2180.87 & 1408.00 & 3143.32 & 2.26 & 1.16 \\
75 & - & 778.33 & 2221.99 & 1443.66 & 3215.00 & 2.24 & 1.00 \\
SEM level & & 8.90 & 51.13 & 48.37 & 33.44 & 0.08 & 0.21 \\
- & White & 752.45 & 2101.89 & 1349.44 & 3135.00 & 2.34 & 1.33 \\
- & Yellow & 784.02 & 2182.82 & 1398.81 & 3123.32 & 2.21 & 0.83 \\
SEM variety & & 7.05 & 37.52 & 36.58 & 28.68 & 0.06 & 0.15 \\
\hline abcd: Means in the same column with different superscript differ significantly $(\mathrm{P}<0.05)$ & & &
\end{tabular}

The interaction between levels of cassava grit and cassava variety of starting broiler chickens as reported in Table 5 was significant $(\mathrm{P}<0.05)$ for the dry matter, ash, ether extract, crude fibre and crude protein digestibility. The values for the dry matter, crude fibre and crude protein digestibility were highest with the birds fed $50 \%$ level of inclusion of yellow cassava grits, while the lowest values were obtained for birds fed 75 $\%$ white cassava grits inclusion level. The values obtained for ash and ether extract digestibility $(\mathrm{P}<0.05)$ increased across the treatments. The values for apparent nutrient digestibility of finishing broiler chickens as shown in Table 6 significantly $(\mathrm{P}<0.05)$ affected the digestibility of dry matter, ash, ether extract, crude fibre and crude protein. The dry matter, ash and crude fibre had the highest digestibility values for birds fed 75 $\%$ yellow cassava grits inclusion level and lowest values were recorded for birds placed on $0 \%$ white cassava grits diet. The digestibility of crude protein was highest at
$50 \%$ white cassava grits inclusion level and lowest at $75 \%$ white cassava grits inclusion level.

\section{Discussion}

The higher average weight obtained for birds fed $50 \%$ white cassava inclusion diet showed the potentials in birds at that inclusion level. Ogunwole et al. (2015) reported the highest final weight for birds fed $50 \%$ inclusion of cassava in the diet. The initial increase and subsequent decrease in feed intake as the substitution level of cassava grits increased might be due to the higher fibre content of the feed with increased cassava grits. Chen et al. (1992) explained that increased fibre content in diet might dilute the energy content of the diet and would probably stimulate higher feed intake, since birds eat to satisfy their energy requirement. Akinfala et al. (2002) also observed an increase in feed intake as the level of cassava meal increased in broiler starter diets. The minimum level of 


\section{Obadimu, Oluwatosin, Sanni and Lala}

Table 5: Effects of cassava grits substitution levels and cassava variety on apparent nutrient digestibility of starting broiler chickens (0-28 days)

\begin{tabular}{ccccccc}
\hline $\begin{array}{c}\text { Substitution level } \\
(\%)\end{array}$ & Variety & $\begin{array}{c}\text { Dry matter } \\
(\%)\end{array}$ & $\begin{array}{c}\text { Ash } \\
(\%)\end{array}$ & $\begin{array}{c}\text { Ether extract } \\
(\%)\end{array}$ & $\begin{array}{c}\text { Crude fibre } \\
(\%)\end{array}$ & $\begin{array}{c}\text { Crude protein } \\
(\%)\end{array}$ \\
\hline 0 & White & $53.53^{\mathrm{abc}}$ & $74.61^{\mathrm{b}}$ & $89.36^{\mathrm{abc}}$ & $79.06^{\mathrm{a}}$ & $81.18^{\mathrm{abc}}$ \\
25 & White & $47.62^{\mathrm{bc}}$ & $85.97^{\mathrm{a}}$ & $89.39^{\mathrm{abc}}$ & $78.78^{\mathrm{a}}$ & $79.63^{\mathrm{cd}}$ \\
50 & White & $49.69^{\mathrm{bc}}$ & $79.13^{\mathrm{b}}$ & $86.23^{\mathrm{cd}}$ & $78.87^{\mathrm{a}}$ & $82.72^{\mathrm{ab}}$ \\
75 & White & $40.36^{\mathrm{c}}$ & $77.08^{\mathrm{b}}$ & $87.11^{\mathrm{bcd}}$ & $75.52^{\mathrm{b}}$ & $78.36^{\mathrm{d}}$ \\
0 & Yellow & $54.39^{\mathrm{abc}}$ & $78.45^{\mathrm{b}}$ & $87.14^{\mathrm{bcd}}$ & $75.54^{\mathrm{b}}$ & $80.79^{\mathrm{bcd}}$ \\
25 & Yellow & $53.57^{\mathrm{abc}}$ & $85.84^{\mathrm{a}}$ & $84.50^{\mathrm{d}}$ & $78.21^{\mathrm{ab}}$ & $79.50^{\mathrm{cd}}$ \\
50 & Yellow & $69.55^{\mathrm{a}}$ & $86.16^{\mathrm{a}}$ & $93.16^{\mathrm{a}}$ & $80.85^{\mathrm{a}}$ & $83.53^{\mathrm{a}}$ \\
75 & Yellow & $62.32^{\mathrm{ab}}$ & $90.99^{\mathrm{a}}$ & $90.73^{\mathrm{ab}}$ & $79.66^{\mathrm{a}}$ & $79.89^{\mathrm{cd}}$ \\
Pooled SEM & & 2.51 & 1.23 & 0.65 & 0.46 & 0.41 \\
0 & - & 58.58 & $76.53^{\mathrm{b}}$ & 88.25 & 79.86 & $83.12^{\mathrm{a}}$ \\
25 & - & 54.51 & $82.64^{\mathrm{a}}$ & 86.97 & 78.49 & $80.98^{\mathrm{a}}$ \\
50 & - & 53.96 & $85.90^{\mathrm{a}}$ & 88.48 & 77.59 & $79.56^{\mathrm{bc}}$ \\
75 & - & 46.97 & $84.03^{\mathrm{a}}$ & 90.13 & 77.30 & $79.12^{\mathrm{c}}$ \\
SEM level & & 5.00 & 1.87 & 1.26 & 0.84 & 0.52 \\
- & White & $47.05^{\mathrm{b}}$ & $79.19^{\mathrm{b}}$ & 88.02 & 78.06 & 80.47 \\
- & Yellow & $59.96^{\mathrm{a}}$ & $85.36^{\mathrm{a}}$ & 88.89 & 78.56 & 80.93 \\
SEM variety & & 3.04 & 1.51 & 0.91 & 0.67 & 0.59 \\
\hline abcd. Means in the same column with different superscript differ significantly (P<0.05) & &
\end{tabular}

Table 6: Effects of cassava grits substitution levels and cassava variety on apparent nutrient digestibility of finishing broiler chickens (28-56 days)

\begin{tabular}{ccccccc}
\hline $\begin{array}{c}\text { Substitution level } \\
(\%)\end{array}$ & Variety & $\begin{array}{c}\text { Dry matter } \\
(\%)\end{array}$ & $\begin{array}{c}\text { Ash } \\
(\%)\end{array}$ & $\begin{array}{c}\text { Ether extract } \\
(\%)\end{array}$ & $\begin{array}{c}\text { Crude fibre } \\
(\%)\end{array}$ & $\begin{array}{c}\text { Crude protein } \\
(\%)\end{array}$ \\
\hline 0 & White & $65.09^{\mathrm{d}}$ & $80.36^{\mathrm{b}}$ & $78.55^{\mathrm{cd}}$ & $82.29^{\mathrm{d}}$ & $82.86^{\mathrm{cd}}$ \\
25 & White & $75.57^{\mathrm{bc}}$ & $82.00^{\mathrm{ab}}$ & $80.57^{\mathrm{abc}}$ & $84.21^{\mathrm{bc}}$ & $83.85^{\mathrm{abc}}$ \\
50 & White & $80.64^{\mathrm{ab}}$ & $82.37^{\mathrm{ab}}$ & $50.71^{\mathrm{abc}}$ & $84.82^{\mathrm{ab}}$ & $84.94^{\mathrm{a}}$ \\
75 & White & $70.44^{\mathrm{cd}}$ & $80.66^{\mathrm{b}}$ & $77.83^{\mathrm{d}}$ & $84.67^{\mathrm{b}}$ & $82.50^{\mathrm{d}}$ \\
0 & Yellow & $71.61^{\mathrm{cd}}$ & $81.88^{\mathrm{ab}}$ & $79.26^{\mathrm{bcd}}$ & $83.44^{\mathrm{cd}}$ & $82.86^{\mathrm{cd}}$ \\
25 & Yellow & $76.00^{\mathrm{abc}}$ & $82.13^{\mathrm{ab}}$ & $82.05^{\mathrm{a}}$ & $85.46^{\mathrm{ab}}$ & $83.54^{\mathrm{bcd}}$ \\
50 & Yellow & $75.79^{\mathrm{abc}}$ & $82.98^{\mathrm{a}}$ & $81.44^{\mathrm{ab}}$ & $84.88^{\mathrm{ab}}$ & $84.70^{\mathrm{ab}}$ \\
75 & Yellow & $82.77^{\mathrm{a}}$ & $84.13^{\mathrm{a}}$ & $82.22^{\mathrm{a}}$ & $85.97^{\mathrm{a}}$ & $84.88^{\mathrm{a}}$ \\
Pooled SEM & & 1.31 & 0.13 & 0.38 & 0.25 & 0.22 \\
0 & - & $78.22^{\mathrm{a}}$ & $81.12^{\mathrm{b}}$ & $78.91^{\mathrm{b}}$ & $85.39^{\mathrm{a}}$ & $84.82^{\mathrm{a}}$ \\
25 & - & $76.21^{\mathrm{a}}$ & $82.07^{\mathrm{ab}}$ & $80.02^{\mathrm{ab}}$ & $84.78^{\mathrm{a}}$ & $83.69^{\mathrm{b}}$ \\
50 & - & $75.29^{\mathrm{a}}$ & $81.82^{\mathrm{ab}}$ & $81.01^{\mathrm{a}}$ & $84.84^{\mathrm{a}}$ & $83.69^{\mathrm{b}}$ \\
75 & - & $68.35^{\mathrm{b}}$ & $83.25^{\mathrm{a}}$ & $81.38^{\mathrm{a}}$ & $82.86^{\mathrm{b}}$ & $82.82^{\mathrm{b}}$ \\
SEM level & & 2.05 & 0.54 & 0.61 & 0.32 & 0.32 \\
- & White & 72.68 & $81.35^{\mathrm{b}}$ & $79.40^{\mathrm{b}}$ & $83.99^{\mathrm{b}}$ & 83.54 \\
- & Yellow & 76.54 & $82.78^{\mathrm{a}}$ & $81.24^{\mathrm{a}}$ & $84.94^{\mathrm{a}}$ & 83.99 \\
SEM variety & & 1.77 & 0.39 & 0.47 & 0.34 & 0.31 \\
\hline abcd: Means in the same column with different superscript differ significantly (P<0.05) & &
\end{tabular}

mortality recorded could be attributed to the processing method of cassava grits. This agrees with the report of Ofuya and Obilo (1993) that treatment of cassava tubers by process such as fermentation allowed for higher inclusion which resulted in lower mortality in broiler chickens. Also, the reduction in crude protein content of the diets as the level of substitution with cassava grits increased could resulted in reduced average final weight as observed by Rafiu et al. (2015).

Higher feed intake of birds as the substitution level of cassava grits increased 


\section{Growth performance and nutrient digestibility of broiler chickens}

at the finishing phase could be as a result of the high crude fibre in the diets. This agrees with the work of Ukachukwu (2008) who reported a significant increase in feed intake with increase in level of composite cassava meals in diets. The fibre content in diet might have diluted the energy content of the diet and would probably stimulate higher feed intake since birds eat to satisfy their energy requirements hence, the increase in feed intake of the birds.

The no particular order of increase or decrease in the digestibility of nutrients at the starter phase as the level of substitution with cassava grits increased in the diets could be as a result of the pelletized nature of the cassava grits which improved nutrient retention and utilization. Adeyemi et al. (2008) recommended pelletizing of cassava diets as a means of improving nutrient retention by broilers.

The improved nutrient digestibility at the finishing phase for bird fed cassava grits showed that the birds can effectively utilized either white or yellow cassava grits, thereby making it possible for the birds to have similar average final weight at the end of the experiment. The pelletized nature of the cassava grits could also have helped improved the digestibility and utilization of the diets (Adeyemi et al., 2008).

\section{Conclusion}

It can be concluded from this study that 50 $\%$ cassava grits can substitute for maize in the starter phase while either white or yellow cassava grits can be substituted for maize up to $75 \%$ inclusion level without adverse effect on the growth of broiler chickens.

\section{References}

Adeyemi, O. A., Eruvbetine, D., Oguntona, T. O., Dipeolu, M. A. and Agunbiade, J. A. 2008. Feeding broiler chicken with diet containing whole cassava root meal fermented with rumen filtrate. Archives Zootechnia, 57(218): 247-258.

Akinfala, E. O. Aderibigbe, A. O. and Matanmi, O. 2002. Evaluation of the nutritive value of whole cassava plant as replacement for maize in the starter diets for broiler chicken. Livestock Research for Rural Development 14:1-6.

Alves, A. A. C. and Setter, T. L. 2000. Response of cassava to water deficit: Leaf area growth and abscisic acid. Journal of Crop Science 40: 131-137.

Anthony, V. P. 2009. Utilization of lowgrade cassava meal (gari) in the diets of egg type chicks (0-8weeks) Pakistan Journal of Nutrition 8:3941

AOAC. 2000. Association of Analytical Chemists Official Methods of Analysis Association of Official Analytical Chemists. $19^{\text {th }}$ edition, Washington DC.

Apata, D. F. and Babalola, T. O. 2012. The use of cassava, sweet potato and cocoyam and their by-products byproducts by non-ruminants. International Journal of Food Science and Nutrition Engineering 2(4): 54-62.

Balogun, T. F and Bawa, G. S. 1997. Cassava peels in the diet of young pigs in Nigeria. Tropical Animal Health and Production 29: 209215.

Charts Bin, 2011. Charts Bin statistics collector, team $2011<$ http: // chartsbin.com/view/1155>

Chen, Y.H., Hsu, J.C. and Yu, B. 1992. Effects of dietary fibre levels on growth performance, intestinal fermentation and cellulose activity of goslings. Journal of Chinese 
Society Animal Science, 21: 12-28.

Iyayi, A. T., Fasanya, O. O. A., and Ayanwole, B. A. 2002 . Reproductive performance of breeding rabbit does fed maize and fermented cassava peel meal. Proceeding $27^{\text {th }}$ Annual Conference of Nigeria Society of Animal Production. NSAP. March 17-21, Federal University of Technology Akure, Nigeria.

Ofuya, C. O. and Obilor, S. N. 1993. The suitability of fermented cassava peel as a poultry feedstuff. Bioresource Technology 44: 101104.

Ogunwole, O. A., Oladimeji, S. O., Abayomi, F. D., Kulakow, P., Iluebbey, $P$. and Tewe, $O$. $O$. 2015. Effects of $\beta$-carotene Biofortified Cassava grits based diets on Retinol Bioavailability and Performance of broiler chicks. Journal of Agricultural Science 7 (10): 187-197.

Oloyede, H. O. B. 2005 All for the love of nutrients, The $78^{\text {th }}$ Inaugural lecture, Library and Publication Committee, University of Ilorin. International Journal of Agricultural Economics and Rural Development 4(2): 89-96
Olurin, K. B., Olujo, E. A. A. and Olukoya, O. A. 2006. Growth of African catfish Clarias gariepinus fingerlings, fed different levels of cassava" World Journal of Zoology (I): 54-56.

Rafiu, T. A., Babatunde, G. M., Giwa, H. O. and Jokodola, O. A. 2015. Effects of replacement of maize with graded levels of cassava grits on growth performance, nutrient utilization and carcass characteristics of broiler chickens International Journal of Agriculture Innovations and Research 3(5): 1527-1531, ISSN 2319-1473.

SAS. 2011. Statistical Analysis Systems. Version 9.3, SAS, Institute Inc. Carry N.C. USA.

Ukachukwu, S. N. 2008. Effect of Composite cassava meal with or without palm oil and/or methionine supplementation on broiler performance Livestock Research for Rural Development, 20(4): 211215.

Received: $5^{\text {th }}$ September, 2018 Accepted: $10^{\text {th }}$ February, 2019 